\title{
Effect of terrigenous sediments on macroalgae functional-form groups of coral reefs in Capurganá, Colombian Caribbean
}

\author{
Ibis Tarini López-Jiménez ${ }^{1}$, Lizette Irene Quan-Young ${ }^{2}$, Lennin Florez-Leiva ${ }^{1}$ \\ ${ }^{1}$ Ocean, Climate and Environment Research Group (OCA), Corporación Académica Ambiental, \\ Universidad de Antioquia, calle 67 No. 53-108, 050010 Medellín, Colombia. \\ (ITL-J) (Corresponding author): E-mail: itlopezj@ gmail.com. ORCID iD: https://orcid.org/0000-0001-7392-2944 \\ (LF-L) E-mail: lennin.fl@ gmail.com. ORCID iD: https://orcid.org/0000-0001-7280-8517 \\ ${ }^{2}$ Grupo Biología CES, Facultad de Ciencias y Biotechnología, Universidad CES, Calle 10A No. 22-04, \\ 050021 Medellín, Colombia. \\ (LIQ-Y) E-mail: lquan@ ces.edu.co. ORCID iD: https://orcid.org/0000-0002-2393-7328
}

\begin{abstract}
Summary: Increased sedimentation in the marine environment has been described as a key factor in the degradation of coral reefs. One of the most important biological components of coral reefs is macroalgae. The objective of this study was to determine whether the effects of terrigenous sediments on macroalgae affect the current state of the coral reef ecosystem. In an in situ experiment in Capurganá Bay, terrigenous sediments were added to artificial plates and the impact on the recruitment and growth of the macroalgae was examined. In this experiment, three treatments were used: sediment addition and two natural conditions, one up to $10 \mathrm{~m}$ distance from the sediment addition (control 1) and one between 15 and $20 \mathrm{~m}$ distance from the sediment addition (control 2). The results indicated a high complexity and variability in the response of reef algae to the effects of sedimentation depending on the sediment grade size deposited. The addition had a positive effect on the recruitment and growth of filamentous algae, primarily red algae, whereas it had a negative effect on coralline algae. The sediments found on the plates did not significantly change the macroalgal structure $(\mathrm{P}>0.05)$. However, a trend was observed in the change of the algal cover in each treatment. These results indicate that there is a wide range of response of the algae depending on the functional groups and the nature of the sediment.
\end{abstract}

Keywords: functional groups; Colombian Caribbean; sedimentation; ecology; phase shift; filamentous algae.

Efecto de los sedimentos terrígenos en grupos morfofuncionales de macroalgas en un arrecife coralino en la bahía Capurganá, Caribe colombiano

Resumen: El aumento de la sedimentación en el medio marino se ha descrito como un factor clave en la degradación de los arrecifes de coral. Uno de los componentes biológicos más importantes de los arrecifes de coral son las macroalgas. El objetivo de este estudio fue determinar si los efectos de los sedimentos terrígenos sobre las macroalgas afectan el estado actual del ecosistema de arrecifes coralinos. En un experimento in situ en la Bahía de Capurganá, se agregaron sedimentos terrígenos a placas artificiales y se examinó el impacto en el reclutamiento y crecimiento de las macroalgas. En este experimento se utilizaron tres tratamientos: adición de sedimentos (SA) y dos condiciones naturales: control 1 (a $10 \mathrm{~m}$ de distancia de la SA), y control 2 (entre 15 y $20 \mathrm{~m}$ de distancia de la SA). Los resultados indicaron una alta complejidad y variabilidad en las respuestas de las algas arrecifales a los efectos de la sedimentación dependiendo del tamaño del grano del sedimento depositado. La adición tuvo un efecto positivo sobre el reclutamiento y crecimiento de algas filamentosas, principalmente algas rojas, mientras que tuvo un efecto negativo sobre las algas coralinas. Los sedimentos encontrados en las placas no cambiaron significativamente la estructura de las macroalgas $(P>0.05)$. Sin embargo, se observó una tendencia en el cambio de la cobertura de algas en cada tratamiento. Estos resultados indican que existe una amplia variedad de respuestas de las algas en función de los grupos funcionales y la naturaleza del sedimento.

Palabras clave: grupos funcionales; Caribe colombiano; sedimentación; ecología; cambio de fase; algas filamentosas.

Citation/Como citar este artículo: López-Jiménez I.T., Quan-Young L.I., Florez-Leiva L. 2021. Effect of terrigenous sediments on macroalgae functional-form groups of coral reefs in Capurganá, Colombian Caribbean. Sci. Mar. 85(2): 125135. https://doi.org/10.3989/scimar.05146.013

Editor: X. Turon.

Received: November 20, 2020. Accepted: March 22, 2021. Published: May 28, 2021.

Copyright: (๑) 2021 CSIC. This is an open-access article distributed under the terms of the Creative Commons Attribution 4.0 International (CC BY 4.0) License. 


\section{INTRODUCTION}

Coral reefs are marine ecosystems present in tropical oceans around the world that provide socio-economic benefits and contribute to the health of the biosphere (Buddemeier et al. 2004, Hughes et al. 2017). Additionally, they are one of the most complex and diverse ecosystems, with high rates of primary production (Barlow et al. 2018) and aesthetic and commercial value, especially with respect to fisheries and tourism (Rendis et al. 2016).

Within reef ecosystems, algae are one of the most important components because they play a critical role in diverse ecological processes, such as forming the base of trophic chains, contributing to the formation and construction of coral reefs, and providing a habitat for various species of ecological and commercial importance (Mumby et al. 2007, Díaz-Pulido et al. 2009). One of the main consequences of coral reef degradation is the coral-algal phase shift, which refers to a change from reefs dominated by corals to reefs dominated by algae (Hughes et al. 2017). This change has a negative effect on the reef ecosystem because it includes a loss of biodiversity, evidenced by the herbivores that live in and feed on the ecosystem (Cheal et al. 2010, López-Jiménez et al. 2020), eutrophication through increased algal growth (Lapointe 1997), the mortality of coral caused by the release of macroalgae through competition for space with corals (Díaz-Pulido et al. 2009), and the rapid degradation in response to numerous anthropogenic drivers (Hughes et al. 2017). A major factor in reef degradation is sedimentation due to coastal development, dredging and other activities, which produce suspended sediments (Kroon et al. 2012). Moreover, sedimentation poses a threat to the persistence of coral reefs because it reduces recovery after disturbance events (Weber et al. 2012, Jones et al. 2016). Sediment can be released into the water column by terrestrial runoff (Fabricius 2005, Kroon et al. 2012), natural resuspension events (Orpin and Ridd 2012) and anthropogenic activities present in the coastal zone (Jones et al. 2016, Hughes et al. 2017). Sediments can either be deposited or remain in the water column, depending on their concentration, grain size, density and buoyancy, as well as the hydrodynamics of the water column (Smith and Friedrichs 2011). This is why excessive sedimentation can adversely affect the structure and function of corals and macroalgae, altering biological processes such as reproduction, metabolism, recruitment, growth, coverage and density (Babcock and Smith 2002, Florez-Leiva et al. 2010). Coral function, coralline alga recruitment and reef calcification rates are also negatively affected (Fabricius and De'Ath 2001), leading to a long-term loss of the coralline alga symbiont community and impairing the future recolonization potential of corals on disturbed reefs (Ricardo et al. 2017). These downstream effects facilitate the growth of fast-growing macroalgae such as turf algae (Kendrick 1991, Díaz-Pulido and McCook 2004).

In the present study, we investigated experimentally the effects of terrigenous sediments on different morphofunctional groups of macroalgae (filamentous turf, fleshy algae and coralline algae) to determine how these effects impact the coral reef's ecosystem during the dry season in Capurganá Bay in the Colombian Caribbean.

\section{MATERIALS AND METHODS}

\section{Study site}

This study was carried out at a coral reef on the coast of Capurganá ( $8^{\circ} 37^{\prime} 08.7^{\prime \prime} \mathrm{N}$ and $\left.77^{\circ} 19^{\prime} 53.6^{\prime \prime} \mathrm{W}\right)$ located in the Gulf of Urabá, Colombian Caribbean (Fig. 1). This zone is mainly dominated by the coral species Acropora palmata, Agaricia tenuifolia, Agaricia undata, Colpophyllia breviserialis, Millepora squarrosa, Diploria labyrinthiformis, Montastraea cavernosa, Porites porites and Siderastrea siderea (Reyes et al. 2010). These species are considered to have been adapted to the natural and anthropogenic geomorphological processes and changes to which the study area is exposed during the dry season (December 2015 to May 2016). The most impactful physical phenomenon for regional intra-annual climatology is the latitudinal displacement of the Intertropical Convergence Zone (ITCZ), which generates contrasting dry and wet climatic seasons (Poveda 2004). In the dry season, from December to March, winds from the north predominately come from the Atlantic, with critical values above $9 \mathrm{~m} \mathrm{~s}^{-1}$ (Chevillot et al. 1993). These winds cause sedimentation conditions to improve as waves and currents intensify, leading to negative effects such as fragmentation and erosion of some coral species (Lonin and Vásquez 2005). The frequent eddies in the region cause sediments to rise with the northerly current (Andrade 1993). In the rainy season, from April to November, the contribution of sediments to the coral reef increases because of the upsurge of the flow of the tributaries into the bay (Andrade 1993) and the southeasterly winds coming from the Pacific Ocean, penetrating the Atrato river basin from the Chocoan coast.

Owing to its semi-closed form, the study area is influenced by the circulation of cyclonic cycles (Panama-Colombia) and by the coastal contraction of the Darien Gulf, which flows eastwards, forming a water recirculation system (Andrade 1993). The drift direction does not allow the sediments of the Atrato delta to be distributed along the length of the gulf, so the deposition of sand is caused mainly by the biological contributions from the Chocó coastline (García-Valencia 2007).

\section{Experimental design and data collection}

The alga assemblages used as the objects of study were selected according to the classification of functional groups by thallus shape, growth rate and similar reproductive strategies (Cetz-Navarro et al. 2015). The morphological groups of these algae used were classified into filamentous turf (FTA), fleshy algae (FA) and coralline algae (CA). The morphology of algae is frequently related to several important functional features, including productivity, respiration, growth rate, reproductive success, longevity, resistance to physical stress, susceptibility to herbivores and competitive ability (Littler and Littler 1980, Littler and Arnold 

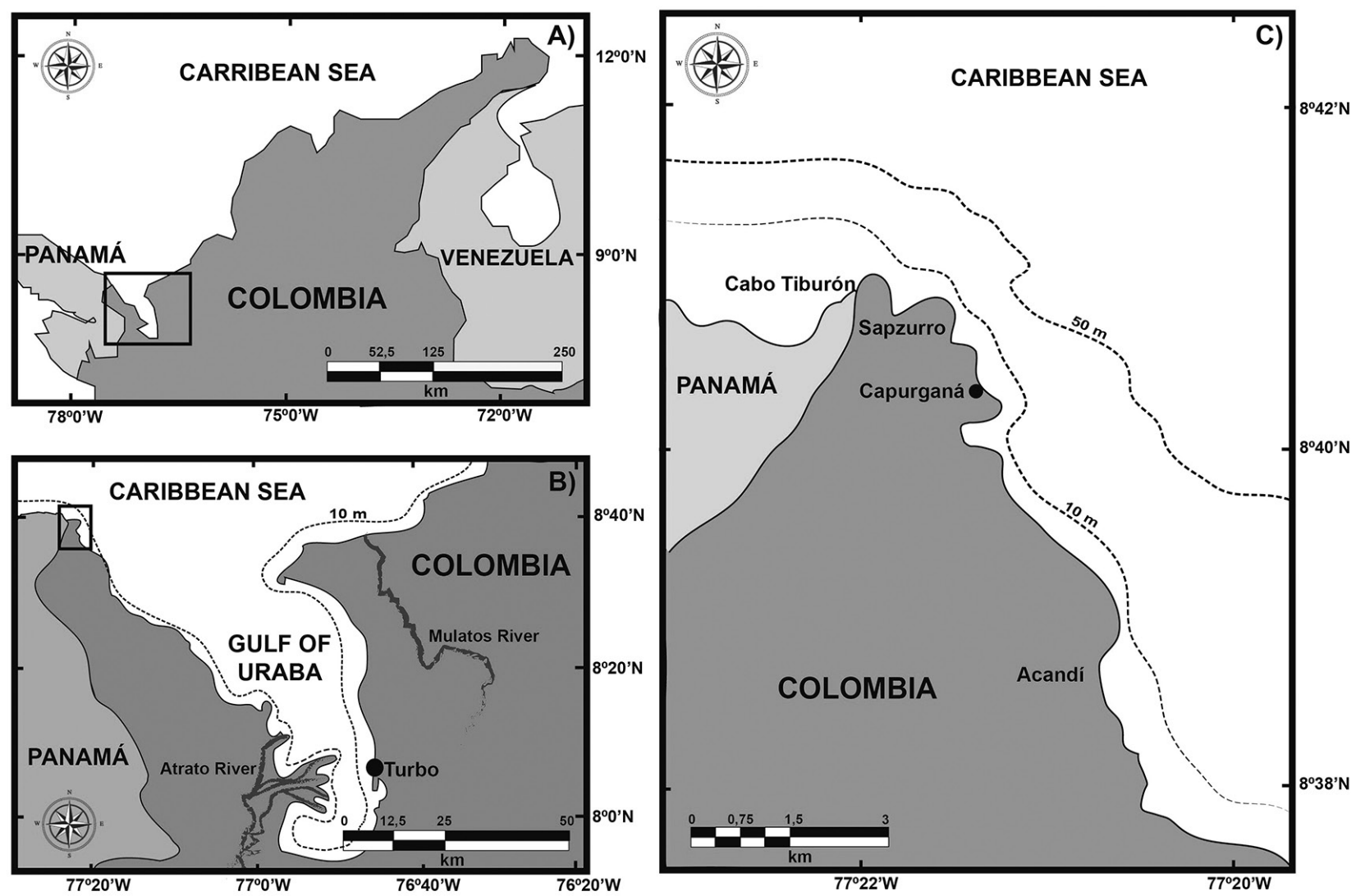

Fig. 1. - The national (A), departmental (B) and regional (C) context of the study.

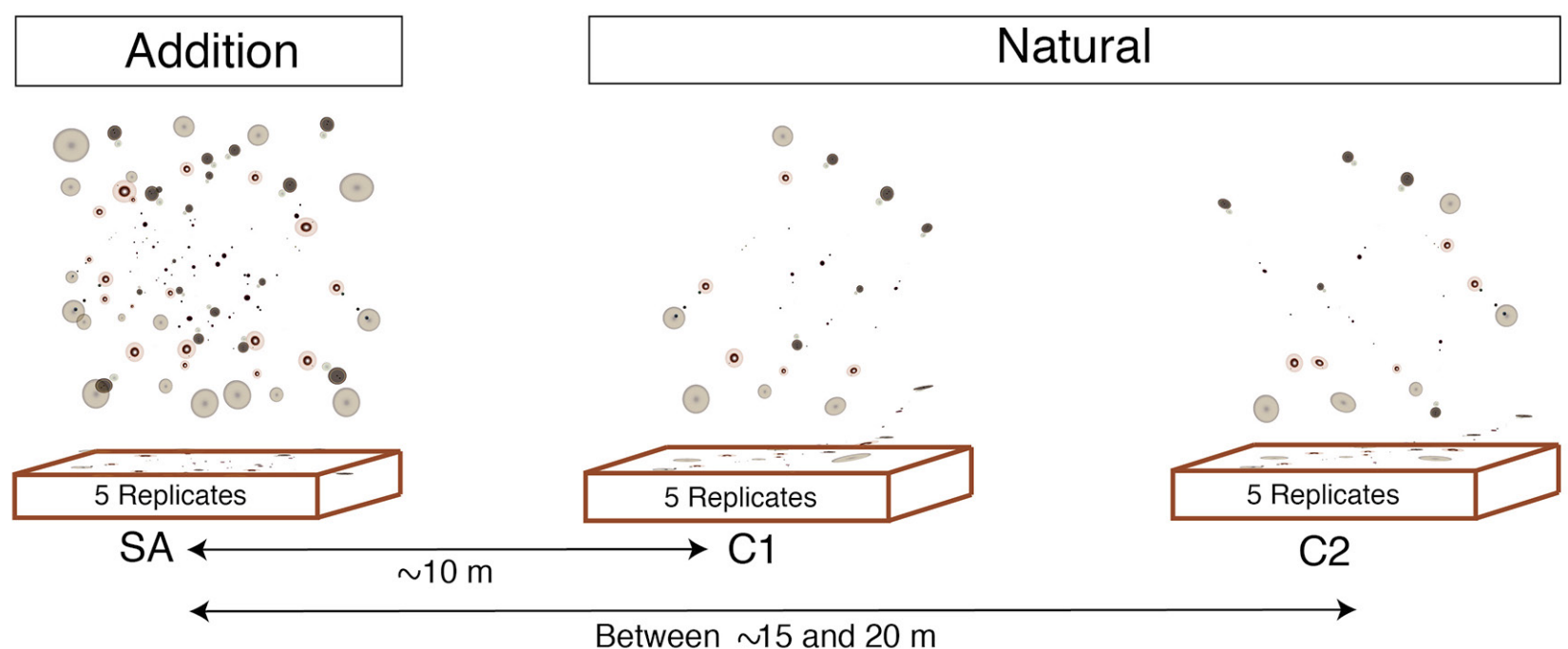

Fig. 2. - Diagram showing the experimental design of sediment additions in an in situ experiment in Capurganá Bay. Three treatments were used: sediment addition and two natural conditions, one up to $10 \mathrm{~m}$ distance from the sediment addition (control 1 ) and one between 15 and $20 \mathrm{~m}$ distance from the sediment addition (control 2).

1982). Based on these observations, morphologically similar algae are usually classified into between six and eight polyphyletic morphological groups, which differ in several ecological characteristics and respond differently to disturbances such as herbivory, desiccation and wave strength (Littler and Littler 1980, Hay 1997).
Thirty recruitment plates (artificial substrate) were installed, consisting of $100 \mathrm{~cm}^{2}$ terracotta plates. They were distributed randomly in the reef at a depth of between 10 and $12 \mathrm{~m}$ and marked according to their function (sediment addition and two natural conditions). They remained in the study area for four weeks 
(the incubation period). One month later, the experimental manipulations of the sediments were initiated immediately. Sediment collected from the Capurganá River was deposited weekly on the recruitment plates for four weeks. Of the natural condition treatments, control 1 plates were up to $10 \mathrm{~m}$ from the sediment addition and control 2 plates were between 15 and 20 $\mathrm{m}$ from the sediment addition (Fig. 2). Two controls were used to take into account that, owing to the water recirculation and the currents present in the area, sedimentation gradients could occur because of the distance from the sediment source. Samples were collected and extracted from the study site using SCUBA diving and then transported to the laboratory using sealed bags (Fig. 2).

The sediments used for the addition treatment were collected from the centre of the Capurganá River $\left(8^{\circ} 26^{\prime} 98.2^{\prime \prime} \mathrm{N}\right.$ and $\left.77^{\circ} 34^{\prime} 72.7^{\prime \prime} \mathrm{W}\right)$ as this side of the Bay directly discharges sediment into the reef ecosystem during the rainy season (Bernal et al. 2005, Arroyave-Rincón et al. 2012). The sediments were collected using an organic driftnet used for limnetic system studies $(<250 \mu \mathrm{m})$, placed perpendicular to the current in the middle of the water column for one hour. The sediments were stored and carried to the laboratory, where they were washed to remove undesirable material (e.g. litter and organisms) and then added to the algal recruitment plates.

The amount of sediment deposited on the plates for the experiment was determined from the natural dry season sedimentation rate $\left(\sim 3.374 \mathrm{~g} \mathrm{~cm}^{-2}\right.$ year $\left.^{-1}\right)$ (Garzón-Ferreira et al. 2000). To determine the experimental sedimentation rates to be used per plate, the adjusted natural sedimentation rate $\left(0.00924388 \mathrm{~g} \mathrm{~cm}^{-2}\right.$ year $^{-1}$ for the dry season) was multiplied by the area of the plate $\left(100 \mathrm{~cm}^{2}\right)$ and by the approximate number of days between each addition. Thereby, a sedimentation rate of $6.47 \mathrm{~g}$ of sediment/week/plate was determined for the experiment in order to understand what happens when the sediment environment is overloaded and how the algae respond to this stressor. This calculated sedimentation rate along with the natural rate of sedimentation constituted the sediment addition treatment and the sedimentation rate used for the controls was the natural one $\left(0.00924388 \mathrm{~g} \mathrm{~cm}^{-2}\right.$ year $\left.^{-1}\right)$.

\section{Data analysis}

The variables considered for this experiment were: i) the percent coverage of the recruited algae, recorded as the number of recruits present on each plate, excluding a $1 \mathrm{~cm}$ rim to avoid any potential edge effects, and ii) the percentage of algae per morphofunctional group.

After the field phase, the percentage of coverage of algal functional groups was also determined using the three categories, FTA, FA, and CA, and the algae were classified by morpho-functional groups according to the development state and the ability to colonize. A microscope and stereoscope were used to more clearly observe the characteristics of the macroalgae. Species were identified by consulting specialized literature (e.g. Littler and Littler 2000).
The granulometric analysis of the sediments was performed using dry screening for the sediment samples from the river with a sieve mesh with openings of between 40 and $140 \mathrm{~mm}$. For the sediment collected from the plates, a wet sieving method was used. The sediments were passed through different mesh filters sized between 80 and $500 \mu \mathrm{m}$ (Álvarez and Bernal 2007).

\section{Statistical analysis}

The assumptions of normality (Shapiro-Wilks test) and homogeneity of variances (Bartlett test) were calculated for the entire experiment. The differences in natural recruitment and the experimental number of recruit species among the treatments were compared using the non-parametric Kruskal-Wallis test. Subsequently, an ANOVA was performed, in which the addition of sediments was the fixed factor, with three levels (river sediments, control 1 and control 2), and replicates $(\mathrm{N}=5)$ were carried out for each treatment. The possibility of type II errors due to the small sample size was taken into account. A multivariate ANOVA was run with recruit coverage and functional groups as independent variables and the three experimental treatments as a factor. Fisher's LSD test was used to detect the minimum significant differences between the treatments. The model had a confidence level of $95 \%$ in the determination of statistically significant effects.

The data were processed using the programming language R-Project (R Core Team 2015), SPSS 25 $5^{\text {th }}$ version (IBM 2017), and Statgraphics Centurión XVI.I (Statpoint Technologies 2009).

\section{RESULTS}

A total of 66 taxa were found, including two infraspecific taxa and coral reef-forming alga species (Table 1). Of these, 33 taxa corresponded to FTA, 21 to FA and 12 to CA. The impact of sedimentation on the algae did not vary in the experiment for either additions or natural conditions $(\mathrm{P}=0.054$, potentially due to a type II error) (Table 2). However, the LSD test showed differences in some treatments (addition and control 2, difference $=-0.758$ ). These analyses showed a trend throughout the experiment, in which, were observed higher values of algae recruitment and growth (mainly FTA) in the treatments with the highest levels of sedimentation and higher AC coverage on the natural conditions (control 2). With the addition of sediment, a higher affinity of the FTA was found, while the FA and CA had a greater presence in control 2.

\section{Effect of sedimentation on macroalgal functional groups}

The three functional groups of algae responded differently to the effects of the sediment addition. The recruitment, cover, and number of species present in the treatments were different, and although there were more species in the sediment addition treatment than in the other treatments, no statistical difference was found $(\mathrm{P}>0.05)$. The addition did not have a negative effect on 
Table 1. - List of species identified in this study on sediment addition plates and natural condition plates (controls 1 and 2). The species indicated with * refer to the most abundant in each group represented in the experiment. FTA, filamentous turf algae; CA, coralline algae; FA, fleshy algae.

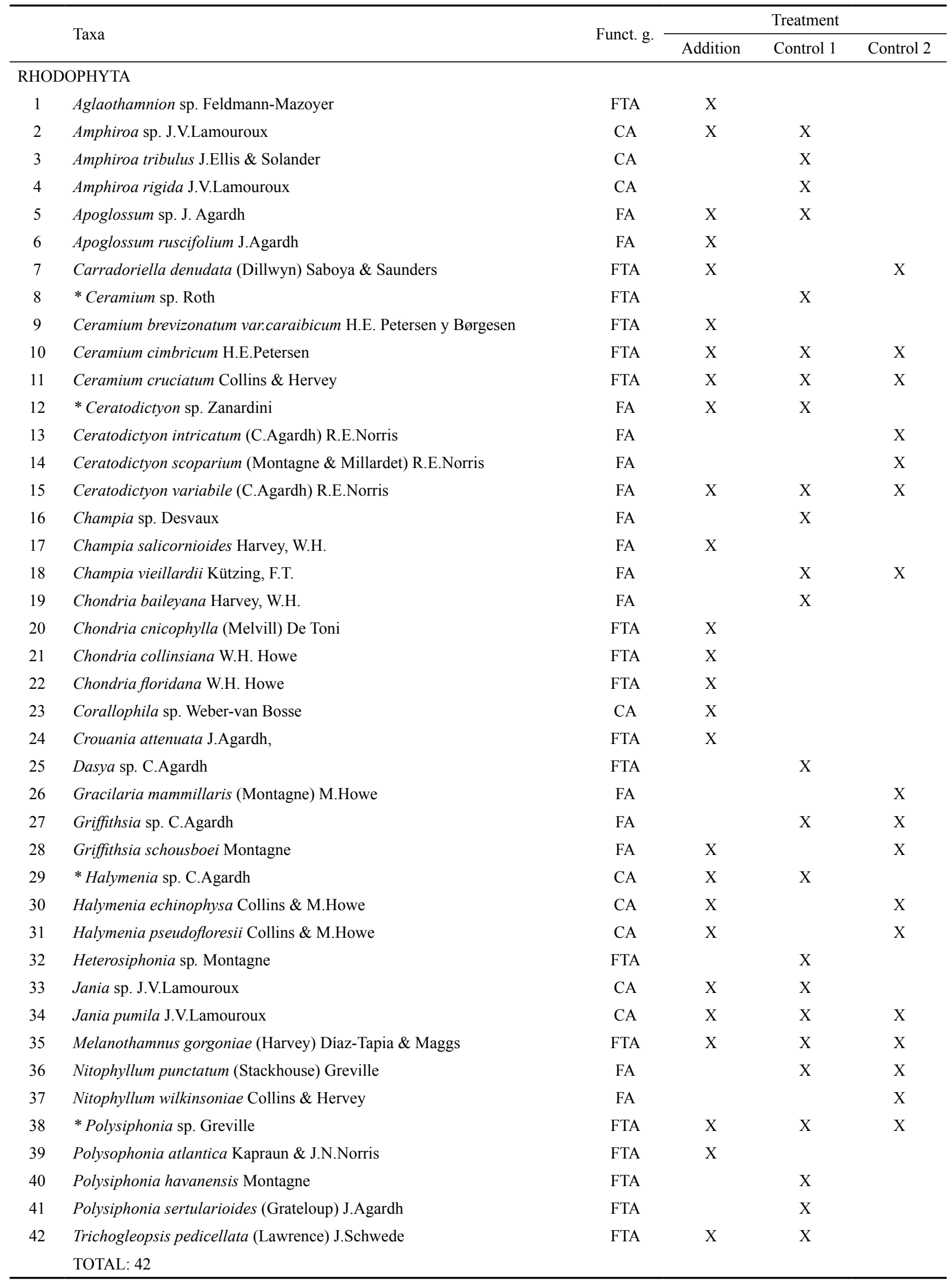




\begin{tabular}{|c|c|c|c|c|c|}
\hline & \multirow{2}{*}{ Taxa } & \multirow{2}{*}{ Funct. g. } & \multicolumn{3}{|c|}{ Treatment } \\
\hline & & & Addition & Control 1 & Control 2 \\
\hline \multicolumn{6}{|c|}{ CHLOROPHYTA } \\
\hline 43 & Bryopsis sp. J.V.Lamouroux & FTA & $\mathrm{X}$ & $\mathrm{X}$ & \\
\hline 44 & Bryopsis plumosa C. Agardh & FTA & & & $\mathrm{X}$ \\
\hline 45 & Bryopsis ramulosa Harvey & FTA & & & $\mathrm{X}$ \\
\hline 46 & Caulerpa cupressoides (Vahl) C. Agardh & $\mathrm{CA}$ & & & $\mathrm{X}$ \\
\hline 47 & Caulerpa lanuginosa J.Agardh & $\mathrm{CA}$ & $\mathrm{X}$ & $\mathrm{X}$ & $\mathrm{X}$ \\
\hline 48 & Caulerpa verticillata J.Agardh & $\mathrm{CA}$ & & & $\mathrm{X}$ \\
\hline 49 & Chaetomorpha sp. Kützing, F.T & FTA & & $\mathrm{X}$ & \\
\hline 50 & * Cladophora sp. Kützing, F.T & FTA & $\mathrm{X}$ & $\mathrm{X}$ & \\
\hline 51 & Cladophora albida Kützing, F.T & FTA & & $\mathrm{X}$ & \\
\hline 52 & Cladophora laetevirens Kützing, F.T & FTA & $\mathrm{X}$ & $\mathrm{X}$ & $\mathrm{X}$ \\
\hline 53 & Cladophora vagabunda (Linnaeus) Hoek & FTA & $\mathrm{X}$ & $\mathrm{X}$ & $\mathrm{X}$ \\
\hline \multirow[t]{2}{*}{54} & Derbesia osterhoutii L.R. Blinks \& A.C.H. Blinks & FA & & & $\mathrm{X}$ \\
\hline & TOTAL: 12 & & & & \\
\hline \multicolumn{6}{|c|}{ OCHROPHYTA- PHAEOPHYCEA } \\
\hline 55 & Dictyopteris delicatula J.V.Lamouroux & FA & $\mathrm{X}$ & $\mathrm{X}$ & \\
\hline 56 & * Dictyota sp. J.V.Lamouroux & FA & $\mathrm{X}$ & $\mathrm{X}$ & \\
\hline 57 & Dictyota caribaea Hörnig \& Schnetter & FA & & $\mathrm{X}$ & \\
\hline 58 & Dictyota humifusa Hörnig \& Schnetter & FA & $\mathrm{X}$ & & $\mathrm{X}$ \\
\hline 59 & Dictyota menstrualis Schnetter, Hörning \& Weber-Peukert & FA & $\mathrm{X}$ & & $\mathrm{X}$ \\
\hline 60 & Feldmannia mitchelliae (Harvey) H.-S. Kim & FTA & & $\mathrm{X}$ & \\
\hline \multirow[t]{2}{*}{61} & Hincksia sp. J.E. Gray & FTA & $\mathrm{X}$ & & \\
\hline & TOTAL: 7 & & & & \\
\hline \multicolumn{6}{|c|}{ CYANOBACTERIA } \\
\hline 62 & * Lyngbya sp. C.Agardh & FTA & $\mathrm{X}$ & & \\
\hline 63 & Lyngbya confervoides C.Agardh & FTA & & & $\mathrm{X}$ \\
\hline 64 & lyngbya majuscula Harvey ex Gomont & FTA & $\mathrm{X}$ & & \\
\hline 65 & Oscillatoria sp. Vaucher ex Gomont & FTA & $\mathrm{X}$ & $\mathrm{X}$ & $\mathrm{X}$ \\
\hline \multirow[t]{2}{*}{66} & Phormidium sp. Kützing ex Gomont & FTA & $\mathrm{X}$ & & \\
\hline & TOTAL: 5 & & & & \\
\hline
\end{tabular}

the cover and appearance of most FTA $(\mathrm{P}=0.245$, mean $60 \pm 0.613 \%)$ and this effect was similar in all the analysed samples (fleshy, $\mathrm{P}=0.658$, mean $27.27 \pm 0.543 \%$; coral, $\mathrm{P}=0.631$, mean $12.73 \pm 0.658 \%$ ) (Table 2). The algal cover was lower under the natural conditions (controls 1 and 2) than under the experimental ones (sediment addition). Although the experiment showed no significant statistical differences, a trend towards a greater presence of FTA and a lower coverage of CA was observed, although in control 2 there was a greater presence of CA than in the other treatments (Fig. 3).

The sediment addition treatment affected the presence of some types of algae (CA $12.73 \%$ ) but showed an increase in the presence of FTA $(47.27 \%$ more than CA) (Table 2). In contrast, on the non-addition plates (control 2) there was a prevalence of FA and CA ( $46.51 \%$ and $23.93 \%$, respectively). In general, in all the experiments, FTA were the group with the high- est presence of algae (52\%), FA were the second most abundant group with $30 \%$, followed by CA with $18 \%$ (Fig. 3). The species composition showed no differences $(\mathrm{P}=0.3819)$ between the plates with the added sediment and those with sediment naturally present in the environment, although a small difference was related to the presence of some exclusive species within the group's functional characteristics present in the treatments. However, there was a greater presence of rhodophytes such as Ceramium sp. and Chondria sp. on the plates with added sediments, and of Polysiphonia sp. on the control plates (Table 1).

Red algae were the most dominant species on all plates of this experiment, in particular FTA (Ceramium cruciatum, Ceramium cimbricum, Gelidiopsis sp., Chondria sp. and Neosiphonia gorgoniae), which formed turfs and covered the settlement plates. Independent of the type of sediment, the fleshy Ceratodic- 
Table 2. - Results of a one-way and multifactorial analysis of variance (ANOVA) on the coverage of species between treatments, a multivariate analysis of variance (MANOVA), a Fisher LSD test and the means with standard deviation for each treatment and morphological group. FTA, filamentous turf algae; CA, coralline algae; FA, fleshy algae; NS, no significance.

\begin{tabular}{|c|c|c|c|c|c|c|c|}
\hline ANOVA & Source & Squares Sum & $\mathrm{df}$ & Half Quadratic & F-ratio & P-value & Conclusion \\
\hline \multicolumn{8}{|c|}{ One-way - every group of macroalgae } \\
\hline \multirow[t]{3}{*}{ FTA } & Between Treatments & 0.0045 & 2 & 0.0022 & 1.58 & 0.245 & NS \\
\hline & Intragroup & 0.0173 & 12 & 0.0014 & & & \\
\hline & Total (correlation) & 0.0218 & 14 & & & & \\
\hline \multirow[t]{3}{*}{$\mathrm{CA}$} & Between Treatments & 0.0001 & 2 & 0.0000 & 0.48 & 0.630 & NS \\
\hline & Intragroup & 0.0020 & 12 & 0.0001 & & & \\
\hline & Total (correlation) & 0.0021 & 14 & & & & \\
\hline \multirow[t]{3}{*}{ FA } & Between Treatments & 0.0002 & 2 & 0.0001 & 0.43 & 0.658 & NS \\
\hline & Intragroup & 0.0038 & 12 & 0.0003 & & & \\
\hline & Total (correlation) & 0.0041 & 14 & & & & \\
\hline \multicolumn{8}{|c|}{ One-way - complete experiment } \\
\hline & Between Treatments & 10.6704 & 2 & 5.3351 & 2.31 & 0.104 & NS \\
\hline & Intragroup & 235.664 & 102 & 2.3104 & & & \\
\hline & Total (correlation) & 246.334 & 104 & & & & \\
\hline \multicolumn{8}{|c|}{ One-way - addition vs. control 2} \\
\hline & Between Treatments & 9.6462 & 1 & 9.6462 & 3.85 & 0.054 & NS \\
\hline & Intragroup & 165.438 & 66 & 2.5066 & & & \\
\hline & Total (correlation) & 175.084 & 67 & & & & \\
\hline \multicolumn{8}{|c|}{ Multifactorial - complete experiment } \\
\hline & A: Treatments & 12.8788 & 2 & 6.4392 & 2.79 & 0.066 & NS \\
\hline & B: Morphological Group & 4.4938 & 2 & 2.2469 & 0.97 & 0.381 & NS \\
\hline & Residual & 231.1705 & 100 & 2.3117 & & & \\
\hline & Total (correlation) & 246.3340 & 104 & & & & \\
\hline \multicolumn{8}{|l|}{ MANOVA } \\
\hline \multirow[t]{2}{*}{ Treatment } & Morphological Group & 2.618 & 2 & 1.309 & 1.628 & 0.201 & NS \\
\hline & Coverage & 10.670 & 2 & 5.335 & 2.309 & 0.105 & NS \\
\hline \multirow[t]{2}{*}{ Total (correlation) } & Morphological Group & 84.629 & 104 & & & & \\
\hline & Coverage & 246.334 & 104 & & & & \\
\hline \multicolumn{8}{|c|}{ FISHER LSD TEST - POST HOC } \\
\hline Treatment & Case & Half & $\begin{array}{l}\text { Homo- } \\
\text { geneous } \\
\text { Groups }\end{array}$ & Contrast & $\begin{array}{l}\text { Differ- } \\
\text { ence }\end{array}$ & Limits & Significance \\
\hline Addition & 38 & 2.5747 & X & $\mathrm{Add}-\mathrm{C} 1$ & -0.1279 & 0.6963 & 0.071 \\
\hline Control 1 & 37 & 2.7027 & $\mathrm{XX}$ & Add $-\mathrm{C} 2$ & -0.7585 & 0.7363 & $0.044 *$ \\
\hline Control 2 & 30 & 3.3333 & $\mathrm{X}$ & $\mathrm{C} 1-\mathrm{C} 2$ & -0.6306 & 0.7407 & 0.094 \\
\hline \multicolumn{8}{|c|}{ MEANS WITH STANDARD DEVIATION } \\
\hline & Turf & Coralline & Fleshy & & & & \\
\hline Addition & $60.00 \pm 0.613$ & $12.73 \pm 0.658$ & $27.27 \pm 0.543$ & & & & \\
\hline Control 1 & $58.82 \pm 0.902$ & $16.18 \pm 0.786$ & $25.35 \pm 0.522$ & & & & \\
\hline Control 2 & $29.47 \pm 0.785$ & $23.93 \pm 0.866$ & $46.61 \pm 0.593$ & & & & \\
\hline
\end{tabular}




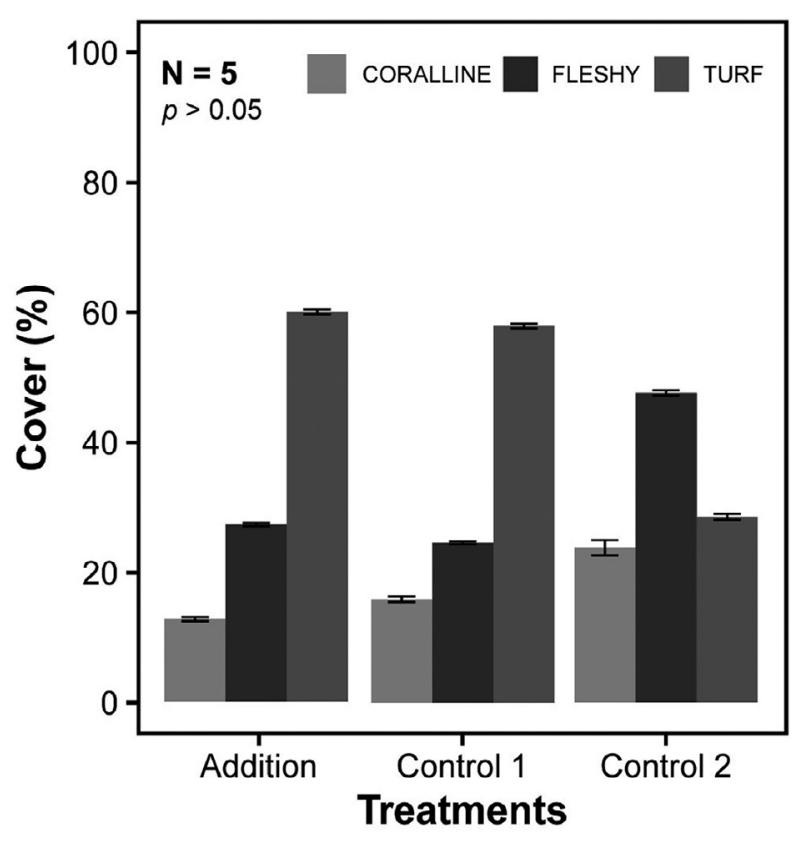

Fig. 3. - The total species of macroalgae in each functional group per treatment with the error bars showing the standard deviation indicating the variation in data measurement.

tyon variabile and the coralline Jania pumila were the most dominant, along with green FTA such as Cladophora laetevirens and Cladophora vagabunda, and CA such as Caulerpa lanuginosa.

Therefore, it can be said that there was no significance between the addition of sediments and the natural conditions, so the sediments did not greatly alter the macroalgal composition in the substrates used (Table 1).
The sediments found on the plates generally corresponded to those naturally present in the environment, because the largest amount of sediments collected from the plates had very small particle sizes (0.53-0.27 $\mathrm{mm})$. However, it was found that on the plates with addition of sediment grain sizes were larger (related to the addition of terrigenous origin) and the presence of macroalgae was greater. Conversely, in the natural conditions, the presence of this functional group was lower (Fig. 4). It should be noted that some species of CA were found in both the addition and natural conditions, but they were present in smaller quantities than FA and FTA. It was also observed that the plates with sediment treatment had a greater presence of red and green algae, represented in greater abundance by FTA. Increases in sediment generally favoured the growth and recruitment of these macroalgae at the level of addition evaluated.

\section{DISCUSSION}

In this experiment, it was observed that the increase in sedimentation at the levels explored had a very slight effect on the structure of the algal community in Capurganá Bay. The three functional groups of algae explored responded differently to the effects of the sediment addition, as this can change the physicochemical characteristics of the benthic zone and promote the presence and development of some algal species, primarily FTA (Birrell et al. 2005, Eriksson and Johansson 2005, Balata et al. 2007).

The addition of sediments increased the presence of FTA but had a negative effect on the presence of FA and CA. Some species, however, appeared mainly in one treatment or another, but with very low abundances

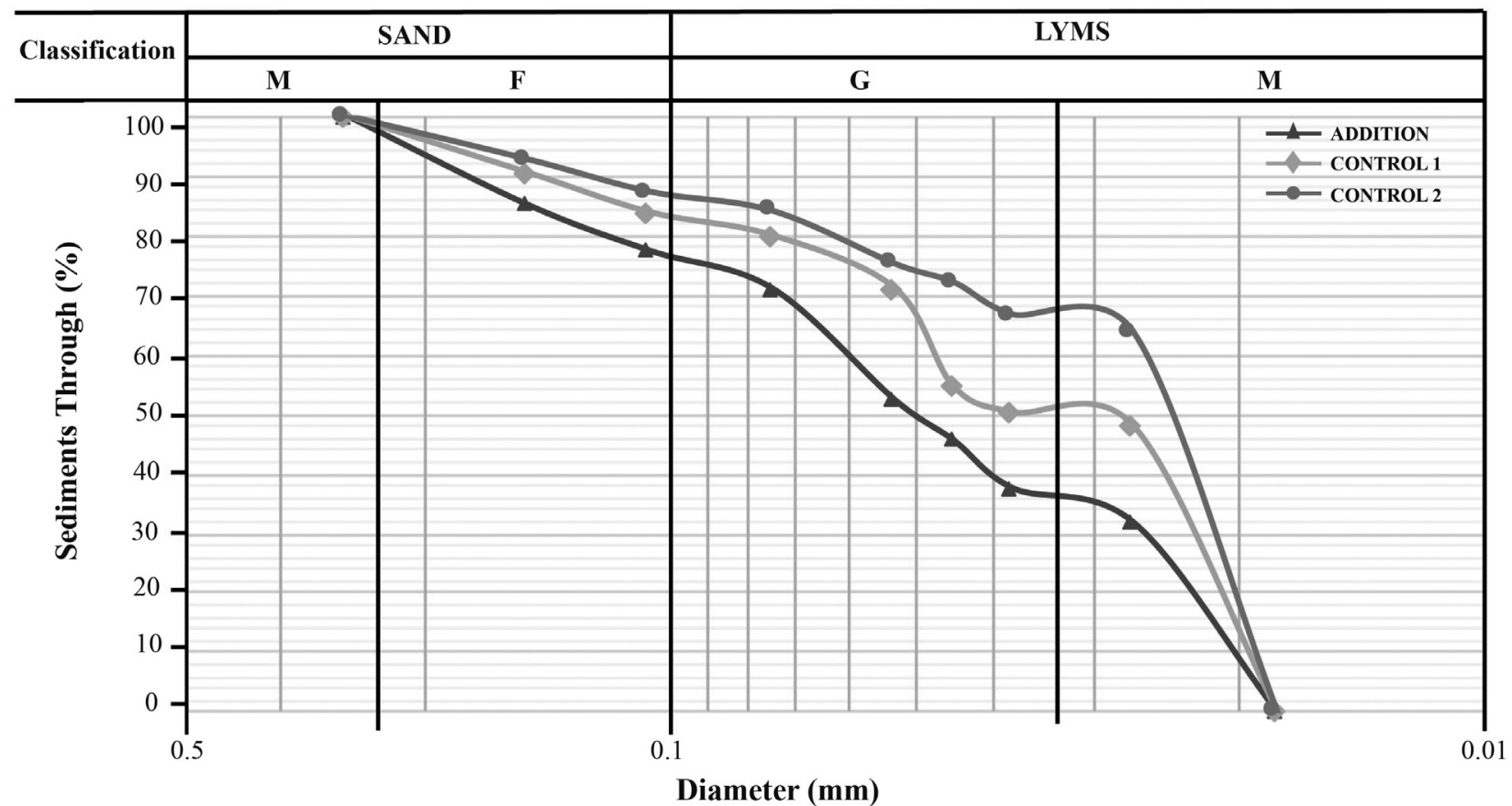

Fig. 4. - Comparison of the granulometric distribution curve found in the different treatments, where $\mathrm{G}$ is gross, $\mathrm{M}$ is medium and $\mathrm{F}$ is fine. The scale of the graph was adapted from Espinace (1979). 
(Table 1). Although no statistically significant differences were found, the observations show a trend towards a greater presence of FTA throughout the experiment, potentially due to a type II error as a consequence of the low number of replicates. It has been found that some macroalgae can take advantage of sediment-rich habitats, including thicker stalk growth, apical growth, vegetative propagation, regeneration of basic structures, temporal reproduction cycles, and growth due to fluctuations in sediment cover (Airoldi and Cinelli 1997, García and Díaz-Pulido 2006), while others can be negatively affected by these habitats (Kendrick 1991, Fabricius and De'Ath 2001). The greater presence of FTA may be due to their ability to retain or trap more sediment particles from river or continental discharges than other morphofunctional groups (Birrell et al. 2005, Quan-Young and Espinoza-Avalos 2006, Tebbett et al. 2018). This why their dominance in areas with high sedimentation rates has mainly been attributed to the fact that they act as natural sediment traps, accumulating large amounts of fine sediments (Acosta-González et al. 2013, Cetz-Navarro 2015). The turfs accumulate organic matter rich in phosphorus and other nutrients necessary for optimal growth, and this favours the proliferation of these communities over the rest of the functional groups (Purcell and Bellwood 2001, Eriksson and Johansson 2005, Quan-Young and Espinoza-Avalos 2006). They may remain in conditions of high sedimentation-unlike some corals and other algal groups-because they have developed the ability to take up and store sediment (D'Antonio 1986, Babcock and Smith 2002, Cetz-Navarro et al. 2015). On the other hand, the reduction in the presence of CA due to the increase in sediments involves some limitations for their settlement and development (Díaz et al. 1996, Doropoulos and Díaz-Pulido 2013), because they are associated with environments with low sedimentation, which is decisive for promoting calcification rates and coral settlement on reefs (Kendrick 1991, Fabricius and De'Ath 2001). High sedimentation causes suffocation in CA, causing them to lose pigmentation or discolour (bleach). It also reduces the light available for the development of these algae, which can lead to the long-term loss of the CA community, limiting future recolonization of previously disturbed reefs (Ricardo et al. 2017). The increase in sedimentation is a problem that coral reefs and CA suffer from globally (Fabricius and De'Ath 2001), because it reduces the availability of space for the settlement of coral larvae and CA, which can cause the death of some coral species by suffocation, reducing the growth of coral by abrasion and decreasing the activity of zooxanthellae among other deleterious effects (Florez-Leiva et al. 2009, Bégin et al. 2016, Ricardo et al. 2017).

Capurganá Bay is subject to a high degree of anthropogenic influence, including tourism, continental discharge of rivers, overfishing, herbivore fishing and direct sewer drainage to the sea. These stressors have caused a greater growth of algae, an accumulation of pollutants in sediments and marine species, and a reduction of light. Higher levels of nutrients and a decrease in the transparency of the water indicate a higher concentration of pollutants (suspended sediments, nitrogen and phosphorous), which leads to more algae and less coral diversity (López-Jiménez et al. 2020). It should be noted that the increase in sedimentation rates is a major problem in coral reefs worldwide, causing mortality in reef species such as hard corals and greatly increasing the space available for alga colonization (Díaz-Pulido and McCook 2004, Bégin et al. 2016). However, this space can primarily be occupied by FTA, which are excellent sediment traps and much more resistant (Airoldi 2003) than the other functional groups evaluated. The prevailing view is that the effects of sedimentation on the coral reef ecosystem depend mainly on the community structure, the interaction with other biological, physical, and chemical factors and, to a large extent, the frequency of sedimentation events in the environment (Babcock and Smith 2002, Birrell et al. 2005). Nonetheless, it is important to clarify that there are algae that have natural variations and cycles that depend completely on factors specific to each species or environmental variable characteristic of each climatic season (e.g. temperature, salinity and light intensity), without necessarily affecting the health of the coral colonies (Márquez and Díaz 2005).

In the present study, relatively low sedimentation rates were used when compared with other studies, in which sediment experiments used higher sedimentation rates and the nature of the sediment was evaluated (Babcock and Smith 2002, Florez-Leiva et al. 2009). Experimental studies with algae have shown that high levels of sediment decrease the fixation of microscopic states, limit the fixation of propagules and recruitment (Balata et al. 2007, Florez-Leiva et al. 2009), and produce a reduction in the sizes of the thallus and reproductive capacity (Birrell et al. 2005). In summary, there are a great variety of responses from algal communities to the addition of different types of sediments, and the responses largely depend on the geographic, geomorphological and natural levels and types of sediments deposited in the ecosystem. Thus, these processes promote reef degradation and can modify the population dynamics and recruitment of algae in Capurganá Bay, which may have important implications for understanding the ecology of this ecosystem.

Finally, for the treatments studied we found that the responses depended to a large extent on the characteristics and nature of the deposited sediments and exhibited high taxonomic richness, which was observed in all the substrates (plates) of the experiment. Given the complex interactions between the nature of the sediment and the algae in this study, it is difficult to make generalizations about their role in algal communities by morphofunctional groups, although these provide a relevant degree of information. Hence, in this experiment, it was important to identify the species to a more specific taxonomic category. Nonetheless, at the experimental level, this study shows the importance of the nature of the sediments and their potential effects on the structure of algal communities in these reef systems. The intensity of the sedimentation effect was evidenced by the amount of sediments added in addition to the type of algae studied. The adaptation responses 
of the algae to the sediments in each of the experimental treatments depended on the species involved in the interaction, their intrinsic properties, type and strategy of growth, their susceptibility to herbivores and their affinity with the sediments. These are some of the properties that may explain the patterns observed in this study concerning the frequency and appearance of one species of algae or another. Due to the multiple and intricate interactions between sediments and algae in this study, it is difficult to draw conclusions about their role in algal communities. However, at an experimental level, this work shows the importance of studying and knowing the presence of sediments and the sediments rate and their possible effects on the structure of algal communities in coral ecosystems.

\section{ACKNOWLEDGEMENTS}

This study was possible thanks to the support of the Corporación Académica Ambiental and the LimnoBase and Biotamar research group of the Institute of Biology of the Universidad de Antioquia. For his support in the field, we thank Jose Caly Uparela and the Dive and Green dive centre.

\section{REFERENCES}

Acosta-González G., Rodríguez-Zaragoza F.A., Hernández-Landa R.C., et al. 2013. Additive diversity partitioning of fish in a Caribbean coral reef undergoing shift transition. PLoS ONE 8: e65665.

https://doi.org/10.1371/journal.pone.0065665

Airoldi L. 2003. The effects of sedimentation on rocky coast assemblages. Oceanogr. Mar. Biol. Annu. Rev. 41:169-171. https://doi.org/10.1201/9780203180570-23

Airoldi L., Cinelli F. 1997. Effects of sedimentation on subtidal macroalgal assemblages: an experimental study from a Mediterranean rocky shore. J. Exp. Mar. Biol. Ecol. 215: 269-288. https://doi.org/10.1016/S0022-0981(96)02770-0

Álvarez A.M., Bernal G.R. 2007. Estimación del campo de transporte neto de sedimentos en el fondo de Bahía Colombia con base en análisis de tendencia del tamaño de grano. Avances en recursos hidráulico 16: 41-50.

Andrade C. 1993. Análisis de la velocidad del viento en el mar Caribe. Bol. Cient. CIOH 13: 33-44. https://doi.org/10.26640/22159045.53

Arroyave-Rincón A., Blanco J.F., Taborda A. 2012. Exportación de sedimentos desde cuencas hidrográficas de la vertiente oriental del golfo de Urabá: influencias climáticas y antrópicas. Rev. Ing. Univ. Med. 11:13-30.

Babcock R., Smith L. 2002. Effects of sedimentation on coral settlement and survivorship. Proc. 9th Inter. Coral Reef Symposium, Bali, 23-27 October 2000.

Balata D., Piazzi L., Cinelli F. 2007. Increase of sedimentation in a subtidal system: effects on the structure and diversity of macroalgal assemblages. J. Exp. Mar. Biol. Ecol. 351: 73-82. https://doi.org/10.1016/j.jembe.2007.06.019

Barlow J., França F., Gardner T.A., et al. 2018. The future of hyperdiverse tropical ecosystems. Nature 559: 517-526. https://doi.org/10.1038/s41586-018-0301-1

Bégin C., Schelten CK, Nugues M.M., et al. 2016. Effects of protection and sediment stress on coral reefs in Saint Lucia. PLoS ONE 11: e0146855. https://doi.org/10.1371/journal.pone.0146855

Bernal G., Montoya L.J., Garizábal C., et al. 2005. La complejidad de la dimensión física en la problemática costera del golfo de Urabá, Colombia. Gestión y Ambiente 8: 123-135.

Birrell C.L., McCook L.J., Willis B.L. 2005. Effects of algal turfs and sediment on coral settlement. Mar. Pollut. Bull. 51: 408-414.

https://doi.org/10.1016/j.marpolbul.2004.10.022
Buddemeier R.W., Kleypas J.A., Aronson R.B. 2004. Coral reefs \& global climate change. Potential contributions of climate change to stress on coral reef ecosystems. Pew Center on Global Climate Change, Virginia, USA, 44 pp.

Cetz-Navarro N.P., Quan-Young L.I., Espinoza-Avalos J. 2015. Morphological and community changes of turf algae in competition with corals. Sci. Rep. 5: 12814 https://doi.org/10.1038/srep12814

Cheal A.J., MacNeil M.A., Cripps E., et al. 2010. Coral-macroalgal phase shifts or reef resilience: links with diversity and functional roles of herbivorous fishes on the Great Barrier Reef. Coral Reefs 29: 1005-1015. https://doi.org/10.1007/s00338-010-0661-y

Chevillot P., Molina A., Giraldo L., et al. 1993. Estudio geológico e hidrológico del golfo de Urabá. Bol. cient. CIOH 14: 79-90 https://doi.org/10.26640/22159045.62

D'Antonio C.M. 1986. Role of sand in the domination of hard substrata by the intertidal alga Rhodomela larix. Mar. Ecol. Prog. Ser. 27: 263-275. https://doi.org/10.3354/meps027263

Díaz J.M., Sánchez J.A., Díaz-Pulido G. 1996. Geomorfología y formaciones arrecifales recientes de Isla Fuerte y Bajo Bushnell, plataforma continental del Caribe colombiano. Bol. Inv. Mar. Cost. 25: 87-105. https://doi.org/10.25268/bimc.invemar.1996.25.0.372

Díaz-Pulido G., McCook L.J. 2004. Effects of live coral, epilithic algal communities and substrate type on algal recruitment. Coral Reefs 23: 225-233. https://doi.org/10.1007/s00338-004-0370-5

Díaz-Pulido G., McCook L.J., Dove S., et al. 2009. Doom and boom on a resilient reef: climate change, algal overgrowth and coral recovery. PLoS ONE 4: e5239. https://doi.org/10.1371/journal.pone.0005239

Doropoulos C., Díaz-Pulido G. 2013. High CO2 reduces the settlement of a spawning coral on three common species of crustose coralline algae. Mar. Ecol. Prog. Ser. 475: 93-99. https://doi.org/10.3354/meps 10096

Eriksson B.K., Johansson G. 2005. Effects of sedimentation on macroalgae: species-specific responses are related to reproductive traits. Oecologia 143: 438-448. https://doi.org/10.1007/s00442-004-1810-1

Espinace R. 1979. Analisis granulometrico por tamizado. Manual de laboratorio de granulometria. Universidad Católica de Valparaíso, Chile.

Fabricius K.E. 2005. Effects of terrestrial runoff on the ecology of corals and coral reefs: review and synthesis. Mar. Poll. Bull. 50: 125-146. https://doi.org/10.1016/j.marpolbul.2004.11.028

Fabricius K., De'Ath G. 2001. Environmental factors associated with the spatial distribution of crustose coralline algae on the Great Barrier Reef. Coral Reefs 19: 303-309. https://doi.org/10.1007/s003380000120

Florez-Leiva L., Rangel-Campo A., Díaz-Ruiz M., et al. 2009. Respuesta de las especies macroalgales a las adiciones de varios tipos de sedimentos: un bioensayo en arrecifes del Parque Nacional Natural Tayrona. Rev. Intrópica 4: 111-119.

Florez-Leiva L., Rangel-Campo A., Díaz-Ruiz M. et al. 2010. Efecto de la sedimentación en el reclutamiento de las macroalgas Dictyota spp. y Lobophora variegata: un estudio experimental en el Parque Nacional Natural Tayrona, Caribe colombiano. Bol. Inv. Mar. Cost. 39: 41-56. https://doi.org/10.25268/bimc.invemar.2010.39.1.141

García-Valencia C. 2007. Atlas del Golfo de Urabá: una mirada al Caribe de Antioquia y Chocó. Santa Marta, Colombia: INVEMAR. 188 pp.

García C.B., Díaz-Pulido G. 2006. Dynamics of a macroalgal rocky intertidal community in the Colombian Caribbean. Bol. Inv. Mar. Cost. 35: 7-18 https://doi.org/10.25268/bimc.invemar.2006.35.0.213

Garzón-Ferreira J., Gil-Agudelo D., Marin B., et al. 2000. Evaluación preliminar de algunos indicadores de contaminación de origen terrestre en áreas coralinas de la región de Santa Marta, Caribe colombiano. Informe de Resultados, pp. 55.

Hay M.E. 1997. The ecology and evolution of seaweed-herbivore interactions on coral reefs. Coral Reefs 16: 67-76. https://doi.org/10.1007/s003380050243

Hughes T.P., Barnes M.L., Bellwood D. R., et al. 2017. Coral reefs in the Anthropocene. Nature 546: 82-90. https://doi.org/10.1038/nature22901 
Jones R.J., Bessel-Browne P., Fisher R., et al. 2016. Assessing the impacts of sediments on corals. Mar. Pollut. Bull. 102: 9-29. https://doi.org/10.1016/j.marpolbul.2015.10.049

Kendrick G.A. 1991. Recruitment of coralline crusts and filamentous turf algae in the Galapagos archipelago: effect of simulated scour, erosion and accretion. J. Exp. Mar. Biol. Ecol. 147: 47-63. https://doi.org/10.1016/0022-0981(91)90036-V

Kroon F.J., Kuhnert P.M., Henderson B.L., et al. 2012. River loads of suspended solids, nitrogen, phosphorus and herbicides delivered to the Great Barrier Reef lagoon. Mar. Pollut. Bull. 65: 167-181. https://doi.org/10.1016/j.marpolbul.2011.10.018

Lapointe B.E. 1997. Nutrient thresholds for bottom-up control of macroalgal blooms and coral reefs. Limnol. Oceanogr. 44:1586-1592. https://doi.org/10.4319/10.1999.44.6.1586

Littler M.M., Arnold K.E. 1982. Primary productivity of marine macroalgal functional form groups from southwestern North America. J. Phycol. 18: 307-311. https://doi.org/10.1111/j.1529-8817.1982.tb03188.x

Littler M.M., Littler D.S. 1980. The evolutions of thallus form and survival strategies in benthic marine macroalgae: field and laboratory test of and functional: forms model. Am. Nat. 116: $25-44$ https://doi.org/10.1086/283610

Littler D. S. Littler M.M. 2000. Caribbean Reef Plants. OffShore Graphics, Inc., Washington, D. C., 542 pp.

Lonin S., Vásquez J. 2005. Hidrodinámica y distribución de coliformes en el golfo de Urabá. Bol. Cient. CIOH 23: 76-89. https://doi.org/10.26640/22159045.140

López-Jiménez I.T., Flórez-Leiva L., Quan-Young L.I. 2020. Influencia de la herbivoría sobre la interacción alga-coral en un arrecife coralino de bahía Capurganá, Caribe colombiano. Rev. Biol. Trop. 68: 729-742. https://doi.org/10.15517/rbt.v68i3.38760

Márquez J.C., Díaz J.M. 2005. Interacciones entre corales y macroalgas: dependencia de las especies involucradas. Bol. Inves. Mar. Cost. 34: 227-242. https://doi.org/10.25268/bimc.invemar.2005.34.0.242

Mumby P.J., Hastings A., Edwards H.J. 2007. Thresholds and the resilience of Caribbean coral reefs. Nature 450: 98-101. https://doi.org/10.1038/nature06252
Orpin A., Ridd P. 2012. Exposure of inshore corals to suspended sediments due to wave resuspension and river plumes in the central Great Barrier Reef: a reappraisal. Cont. Shelf Res. 47: $55-67$

https://doi.org/10.1016/j.csr.2012.06.013

Poveda G. 2004. La hidroclimatología de Colombia: una síntesis desde la escala inter-decadal hasta la escala diurna. Rev. Acad. Col. Cien. 28: 201-222.

Purcell S., Bellwood D. 2001. Spatial patterns of epilithic algal and detrital resources on a windward coral reef. Coral Reefs 20: $117-125$.

https://doi.org/10.1007/s003380100150

Quan-Young L.I., Espinoza-Avalos J. 2006. Reduction of zooxanthellae density, chlorophyll $a$ concentration, and tissue thickness of the coral Montastraea faveolata (Scleractinia) when competing with mixed turf algae. Limnol. Oceanogr. 51: 1159-1166. https://doi.org/10.4319/10.2006.51.2.1159

Rendis A.M., Acosta-González G., Hernández-Stefanoni J.L., et al. 2016. Quantifying the reefscape transformation of a coastal Caribbean coral reef during a phase shift and the associated coastal landscape change. Mar. Ecol. 37: 697-710. https://doi.org/10.1111/maec.12334

Reyes J., Santodomingo N., Flórez P. 2010. Corales escleractinios de Colombia. INVEMAR, Serie de Publicaciones Especiales, No. 14. Santa Marta, 246 pp.

Ricardo G.F., Jones R.J., Nordborg M., et al. 2017. Settlement patterns of the coral Acropora millepora on sediment-laden surfaces. Sci. Total Environ. 609: 277-288. https://doi.org/10.1016/j.scitotenv.2017.07.153

Smith S.J., Friedrichs C.T. 2011. Size and settling velocities of cohesive flocs and suspended sediment aggregates in a trailing suction hopper dredge plume. Cont. Shelf Res. 31: S50-S63. https://doi org/10.1016/j.csr-2010.04.002

Tebbett S.B., Bellwood D.R., Purcell S.W. 2018. Sediment addition drives declines in algal turf yield to herbivorous coral reef fishes: implications for reefs and reef fisheries. Coral Reefs 37: 929-937. https://doi.org/10.1007/s00338-018-1718-6

Weber M., de Beer D., Lott C., et al. 2012. Mechanisms of damage to corals exposed to sedimentation. Proc. Natl. Acad. Sci. 109: E1558-E1567 https://doi.org/10.1073/pnas.1100715109 